\title{
Patterns of host use among alga- and sponge- associated amphipods
}

\author{
Alistair G. B. Poore ${ }^{1, *}$, Megan J. Watson ${ }^{1}$, Rocky de Nys ${ }^{1,2}$, James K. Lowry ${ }^{3}$, \\ Peter D. Steinberg ${ }^{1,2}$ \\ ${ }^{1}$ School of Biological Science and ${ }^{2}$ Centre for Marine Biofouling and Bio-Innovation, University of New South Wales, \\ Sydney, New South Wales 2052, Australia \\ ${ }^{3}$ Division of Invertebrate Zoology, Australian Museum, 6 College Street, Sydney South, New South Wales 2000, Australia
}

\begin{abstract}
Marine amphipods commonly use other organisms as both habitat and/or food, offering an opportunity to contrast host associations in marine environments with that of terrestrial invertebrates. A few species of amphipods have been found to specialise on their hosts for habitat or food; however, their host associations remain poorly described and previous studies have confounded habitat and feeding specificity. We examined the patterns of host use for amphipods associated with macroalgae and sponges. For macroalgae, the analysis was limited to strictly herbivorous species in order to address feeding specificity only. On both hosts, amphipods displayed a range of host specificity, from more generalised to more specialised species. Even when not specialised, amphipod species had disjunct distributions, resulting in a distinct assemblage of amphipods associated with each host species. This was true for both herbivorous amphipods inhabiting algae, where host specificity relates to feeding specificity, and for amphipods on sponges, where host specificity is likely to relate to habitat specificity only. For most species of herbivorous amphipods, patterns of host use were largely unrelated to sampling time (day vs night), remained distinct across seasons, and were unaffected by the presence of alternative food sources (epiphytes).
\end{abstract}

KEY WORDS: Amphipods $\cdot$ Host specificity $\cdot$ Algae $\cdot$ Sponges $\cdot$ Herbivory $\cdot$ Epiphytes

\section{INTRODUCTION}

Host specialisation by invertebrates has been a major focus of ecological and evolutionary research into plant-animal and parasite-host interactions in terrestrial systems (Bernays \& Graham 1988, Futuyma \& Moreno 1988, Jaenike 1990, Thompson 1994). Many marine invertebrates also use other organisms as habitat (commensals), or as both habitat and food (parasites, carnivores and herbivores). Most associations between marine invertebrates and their plant or animal hosts, however, remain poorly described and there are few quantitative data addressing host specificity.

Host associations of free-living marine invertebrates have been most fully described for herbivores inhabit-

*E-mail: a.poore@unsw.edu.au ing algae or seagrasses and, in strong contrast to many terrestrial herbivores, few appear to specialise on their host plants (Hay \& Steinberg 1992). Among insect herbivores, which make up the vast majority of terrestrial herbivore species, approximately $75 \%$ of species feed from within only 1 plant family (Bernays \& Chapman 1994). In contrast, marine herbivores commonly feed from many families and all 3 divisions of macroalgae (Hay \& Steinberg 1992). Some marine herbivores, however, are specialised and it has been argued that an understanding of these rare cases may provide insight into the ecology and evolution of feeding specialisation in general (Hay \& Steinberg 1992). While uncommon in terms of the number of species, specialists occur in many groups of small marine herbivores including amphipods (e.g., Hay et al. 1990), isopods (e.g., Brearley \& Walker 1995) and gastropods (e.g., Jensen 1997). 
The observed differences between marine and terrestrial systems may be largely due to the high levels of host specificity among insects, since other terrestrial herbivores display similar patterns of feeding to those of marine herbivores (Hay \& Steinberg 1992). Many insects have relatively immobile larvae and host choice is determined by specialised oviposition behaviour of mobile adults. In contrast, the larvae of many marine invertebrates are planktonic, disperse widely and may have little opportunity to select hosts. Differences in life histories may thus explain the lack of host specialisation in groups such as urchins or gastropods, many of which have widely dispersing larvae. They cannot, however, explain the apparent lack of specialists among marine invertebrates that brood their young, such as amphipods and isopods.

Amphipods are abundant in most marine environments, and commonly use other organisms as habitat. They occur on algal and seagrass hosts worldwide (Brawley 1992) and also on a wide variety of animal hosts including sponges (Biernbaum 1981, Costello \& Myers 1987), ascidians (Thiel 1999), cnidarians (Vader 1983), echinoderms (Vader 1978), molluscs (Vader 1972) and vertebrates (Rowntree 1996). They have no planktonic stage and release fully formed juveniles into their local environment. Host selection behaviour by adults can thus distribute juveniles onto appropriate hosts in a manner similar to terrestrial insects (Poore \& Steinberg 1999). Of the wide variety of hosts used by amphipods, macroalgae and sponges provide perhaps the best opportunity to contrast patterns of host specificity among marine amphipods with that of terrestrial insects. In common with terrestrial plants, these hosts support high densities of associated invertebrates, are sedentary, and produce a diverse array of biologically active secondary compounds (Hay \& Steinberg 1992, Faulkner 1998).

The host specificity of plant-associated amphipods has been examined from 2 perspectives: the feeding preferences of individual herbivorous species and the comparison of entire amphipod faunas associated with different hosts. These studies have thus addressed 2 distinct aspects of host specificity: feeding and habitat specificity respectively. Amphipods are rarely feeding specialists but do commonly display strong preferences between hosts (e.g., Duffy \& Hay 1991b, Poore \& Steinberg 1999). Contrasts of amphipod species composition across algal (e.g., Edgar 1983a, Lewis 1987) or seagrass hosts (e.g., Stoner 1983, Virnstein \& Howard 1987) have commonly found differences in abundance but not species composition between hosts. Distribution patterns across hosts, however, may be due to habitat or feeding preferences and few studies have separated these possibly confounding factors (see Sotka et al. 1999 for a recent exception). Distributional data may be used to address feeding specificity only if the analyses are limited to those species that exclusively consume their hosts. Such analyses have not been performed for amphipods associated with seagrasses or algae despite a general knowledge of the feeding modes of abundant amphipod taxa (Brawley 1992).

In contrast, the feeding ecology of sponge-associated amphipods is largely unknown and while some have been shown to consume their host sponge, most are assumed to consume external food sources (Oshel \& Steele 1985). It remains of interest, however, to know whether amphipods distribute themselves differentially across hosts. There is anecdotal evidence that certain amphipods associated with sponges are obligate commensals (Vader 1984); however, few studies contain quantitative data contrasting the amphipod fauna on different sponges or addressing levels of host specificity. We would expect that host specificity in sponge-associated amphipods is lower than that among herbivorous amphipods inhabiting macroalgae if feeding specialisation is the most important determinant of host specificity.

To contrast host use by marine amphipods with that of terrestrial insects, we examined patterns of host use for amphipods inhabiting macroalgae, limiting the analysis to strictly herbivorous species, and of commensal amphipods associated with sponges. Herbivorous species were sampled during both day and night as many mesograzers are known to be nocturnally mobile and may decouple the use of hosts as shelter and as food (Brawley 1992). The effect of epiphyte cover on herbivores was also examined, as it has been argued that feeding on food sources external to the host itself reduces the probability of host specialisation (Bell 1991). We asked the following specific questions: (1) What are the patterns of distribution of herbivorous amphipods across algal hosts? (2) To what degree is the associated amphipod fauna predictable from the identity of the algal host species? (3) Is the distribution or composition of herbivorous amphipods affected by time of sampling (day vs night or season) or external food sources (epiphyte cover)? (4) Do sponge-associated amphipods display qualitatively similar patterns of distribution across hosts to that of herbivores inhabiting algae?

\section{METHODS}

Study sites and organisms. Host plant use of herbivorous amphipods inhabiting macroalgae was examined at Shark Bay, Port Jackson, New South Wales,

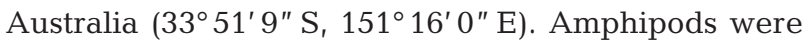
collected from 8 species of brown macroalgae at 0.5 to $2 \mathrm{~m}$ depth: Colpomenia peregrina (Sauvageau) Hamel, 
Dictyopteris acrostichoides (J. Agardh) Boergesen, Dictyota dichotoma (Hudson) Lamouroux, Dilophus marginatus J. Agardh, Zonaria diesingiana J. Agardh, Padina crassa Yamada, Sargassum linearifolium (Turner) C. Agardh and Sargassum vestitum (R. Brown ex Turner) C. Agardh. These algae were abundant at Shark Bay, represented a range of morphological types, and include species with $(D$. acrostichoides, $D$. dichotoma, D. marginatus and $Z$. diesingiana) and without (C. peregrina, P. crassa and Sargassum spp.) non-polar secondary metabolites (Poore \& Steinberg 1999). Algae were identified using the keys in Farrant \& King (1989) and Womersley (1987).

The amphipods considered as herbivores were those from the families Ampithoidae, Biancolinidae and Hyalidae, which were each abundant at Shark Bay (Poore \& Lowry 1997). The ampithoids Ampithoe caddi, A. kava, A. ngana, Cymadusa munnu, Exampithoe kutti, Peramphithoe parmerong and Plumithoe quadrimana are described in Poore \& Lowry (1997). Members of this family are well-known herbivores in algal and seagrass systems worldwide (Brawley 1992). From the Biancolinidae, 1 species was considered, an undescribed species of Biancolina. Species of Biancolina are found in burrows within algal stems and blades and consume algal tissue from within the thallus (Ishimaru 1996, authors' pers. obs.). The free-living Hyale nigra Haswell was the only representative of the Hyalidae considered (local species are described in Barnard 1974). Like ampithoids, hyalids are exclusively herbivorous and abundant in algal and seagrass systems (Brawley 1992).

Host use by sponge-associated amphipods was examined at Bare Island, Botany Bay, New South

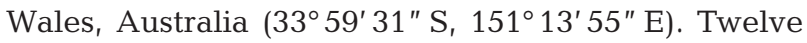
sponge species were collected from 12 to $14 \mathrm{~m}$ depth: Antho (Isopenectya) chartacea Whitelegge, Callyspongia sp. 1, Callyspongia sp. 2, Callyspongia sp. 3, Cymbastella concentrica Lendenfeld, Halichondria sp., Holopsamma laminaefavosa Carter, Iotrochopsamma arbuscula Whitelegge, Mycale (Carmia) sp., Phorbas sp., Phoriospongia cf. kirki, and Raphoxya sp. Sponges were identified by Dr John Hooper (Queensland Museum). One soft coral, Capnella gaboensis Verseveldt, was also sampled because it was abundant among the sponge beds at Bare Island and its associated amphipod fauna included species also found on sponges (see 'Results'). Sponges in the genera Halichondria, Callyspongia, Mycale and Phorbas, and soft corals in the genus Capnella are known to contain biologically active secondary compounds (Blunt \& Munro 1998). The most abundant sponge-associated amphipods were those in the families Leucothoidae and Colomastigidae (well known to be commensals of sponges worldwide, Vader 1984), Stenothoidae (com- monly associated with a wide variety of invertebrate hosts, Vader 1978, 1983), Eusiridae and the endemic Australian species Icilius australis (Icilidae).

Abundance of herbivores on algal hosts. The distribution and abundance of herbivorous amphipods across algal hosts were examined by sampling 5 algal species during the day (09:30 to 10:30 h) and at night (21:00 to $22: 00 \mathrm{~h}, 3 \mathrm{~h}$ after sunset) on 2 consecutive dates in October 1997. At each sampling time, 5 replicate plants were collected from each of Dictyopteris acrostichoides, Padina crassa, Zonaria diesingiana, Sargassum linearifolium and $S$. vestitum. Individuals were haphazardly chosen, and enclosed underwater in $500 \mathrm{ml}$ plastic containers. Samples were fixed in 5\% formalin in seawater, shaken repeatedly in freshwater to remove the associated amphipods, and rinsed through a $300 \mu \mathrm{m}$ sieve. Under a dissecting microscope, all amphipods in the Ampithoidae, Biancolindae and Hyalidae were removed from each sample, sorted to species and counted. The densities (number per $\mathrm{g}$ wet weight of alga) of Ampithoe caddi, A. kava, A. ngana, Exampithoe kutti and Hyale nigra were analysed using ANOVA, with algal species and time of day as fixed factors and sampling date as a random factor. Differences between algal species were contrasted with Tukey's post-hoc test using the mean square estimate of the alga $\times$ date interaction term. Densities of Peramphithoe parmerong and Plumithoe quadrimana on all algal species could not be analysed using ANOVA due to extreme heterogeneity of variance. Densities of Cymadusa munnu and Biancolina sp. were not analysed as too few individuals were sampled.

Differences in the species composition of herbivorous amphipods across algal species and sampling times were analysed using non-metric multidimensional scaling (MDS) and analysis of similarities (ANOSIM) (Clarke \& Warwick 1994). The numbers of each amphipod species per sample were standardised for total abundance. Following MDS, a 2-way ANOSIM was conducted with algal species and sampling time as factors.

Long-term sampling of herbivorous amphipods. The abundance of 8 dominant species of brown algae at Shark Bay is temporally variable (Poore \& Steinberg 1999). To assess whether amphipod distributions remained distinct over time, 3 species of amphipods were sampled from all 8 species of brown macroalgae (see 'Study sites and organisms' above) every 2 mo from July 1996 to March 1997. The amphipods counted were Biancolina sp., which had a highly restricted host range, and 2 amphipods with strongly contrasting distributions across algal hosts, Exampithoe kutti and Peramphithoe parmerong (see 'Results'). Five replicate individuals were sampled from each species of algae (if present) on each sampling date. Sorting details are 
as described previously. Seasonal changes in the densities of these amphipods were not formally analysed as the data sets displayed extreme heterogeneity of variance and missing cells.

Effects of epiphytes on herbivorous amphipod distributions. Epiphytes on macroalgae are commonly thought to provide a major food source for herbivorous amphipods and reduce the likelihood of specific interactions between herbivore and host species (Bell 1991). To investigate the influence of epiphyte cover on the abundance and species composition of herbivorous amphipods, the herbivorous amphipod fauna on clean (largely free of visible epiphytes) and heavily fouled (visually estimated at $>75 \%$ cover of mostly red and brown filamentous algae) individuals of Sargassum linearifolium and Dictyopteris acrostichoides, 2 algal species with very different amphipod species composition (see 'Results'), were compared. The density (number per $g$ wet weight of alga) of all species (except Cymadusa munnu and Plumithoe quadrimana, as none was collected) was analysed using ANOVA, with algal species and epiphyte cover as fixed factors.

Differences in species composition of herbivorous amphipods across algal species and fouling levels were analysed using MDS as described above for the day-night sampling. Seven herbivorous amphipod species were used in the analysis, all except Cymadusa munnu and Plumithoe quadrimana, which were absent from these samples. The ANOSIM following MDS used algal species and epiphyte cover as factors.

Abundance of amphipods on sponge and coral hosts. The distribution and abundance of amphipods across invertebrate hosts were examined by sampling 12 sponge species (listed above) and 1 species of soft coral, Capnella gaboensis, during August 1998. Five replicate individuals of each sponge were enclosed underwater in plastic bags. Confinement in the bags resulted in the amphipods leaving their tubes and crevices, which facilitated sorting (Costello \& Myers 1987). Amphipods were removed from sponges by gently washing the sponge over a $0.5 \mathrm{~mm}$ sieve with freshwater, and fixed in $5 \%$ formalin. Under a dissecting microscope, all gammarid amphipods were sorted to species and counted. Densities of the most abundant amphipods (see 'Results') were not statistically analysed due to extreme heterogeneity of variance - the abundant amphipods were often present on only 1 sponge species.

Amphipod species composition across the 12 sponges and 1 soft coral was compared using MDS as described above for the algal sampling. Samples with no amphipods were removed from the analysis, resulting in 57 samples from 11 sponge species (all initially sampled except Rhapoxya sp.) and 1 soft coral. Following MDS, a 1-way ANOSIM was conducted to contrast host species.
Statistical analyses. ANOVAs were carried out using SYSTAT (Wilkinson 1990). The assumptions of normality and heterogeneity of variance were checked using frequency histograms of residuals and plots of residuals versus means, respectively. Logarithmic or square-root transformations were made where appropriate. MDS analysis and ANOSIM were carried out using PRIMER (Clarke \& Warwick 1994) and used the Bray-Curtis similarity index and fourthroot transformed data standardised for total sample abundance. The significance level was taken as $\mathrm{p}<$ 0.05 .

\section{RESULTS}

\section{Abundance of herbivores on algal hosts}

The herbivorous amphipods sampled displayed distinctive patterns in their abundance across algal species in the field (Fig. 1). Algal species had a significant effect on amphipod densities for all amphipod species except Hyale nigra (Table 1). These patterns were specific to each herbivore species, with closely related amphipods having strongly contrasting distributions. There were no consistent differences between day- and nighttime abundances, with sampling time significantly affecting amphipod densities only for Ampithoe caddi (Table 1). The 3 species of Ampithoe occurred abundantly on Dictyopteris acrostichoides, Sargassum linearifolium and Zonaria diesingiana, and were uncommon on Colpomenia peregrina and $S$. vestitum. Their relative abundance, however, differed slightly between algal species, with $A$. caddi being most abundant on $D$. acrostichoides (Fig. 1a), A. kava most abundant on both $D$. acrostichoides and $S$. linearifolium (Fig. 1b), and A. ngana most abundant on $Z$. diesingiana (Fig. 1c). Exampithoe kutti was very abundant on $D$. acrostichoides and $Z$. diesingiana and rare on the Sargassum spp. and C. peregrina (Fig. 1d). This contrasted strongly with the distribution of Peramphithoe parmerong, which occurs primarily on Sargassum spp. (Fig. 1e). Plumithoe quadrimana was restricted to $C$. peregrina and $Z$. diesingiana, and was the only herbivorous amphipod species to occur abundantly on C. peregrina (Fig. 1f). Hyale nigra had a distribution similar to that of the Ampithoe species, being widespread except for $C$. peregrina and $S$. vestitum (Fig. 1g).

The distinctive patterns of distribution across algal species for individual amphipod species resulted in a characteristic species composition of herbivorous amphipods on each algal host species. In the MDS plot, based on samples standardised to total amphipod abundance, samples grouped strongly according to 

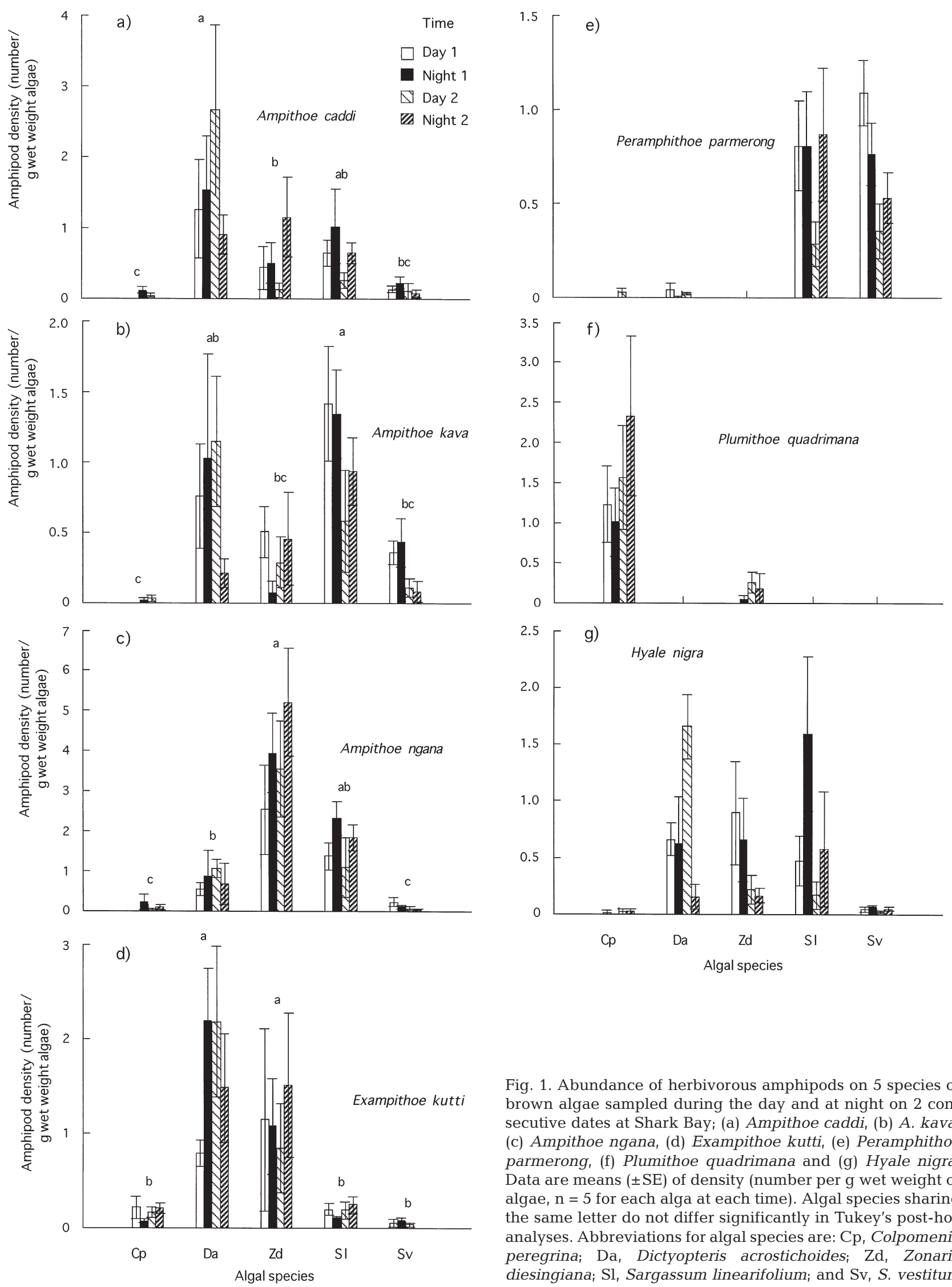

Fig. 1. Abundance of herbivorous amphipods on 5 species of brown algae sampled during the day and at night on 2 consecutive dates at Shark Bay; (a) Ampithoe caddi, (b) A. kava, (c) Ampithoe ngana, (d) Exampithoe kutti, (e) Peramphithoe parmerong, (f) Plumithoe quadrimana and (g) Hyale nigra. Data are means $( \pm \mathrm{SE}$ ) of density (number per g wet weight of algae, $\mathrm{n}=5$ for each alga at each time). Algal species sharing the same letter do not differ significantly in Tukey's post-hoc analyses. Abbreviations for algal species are: $\mathrm{Cp}$, Colpomenia peregrina; Da, Dictyopteris acrostichoides; Zd, Zonaria diesingiana; $\mathrm{Sl}$, Sargassum linearifolium; and $\mathrm{Sv}_{1} \mathrm{~S}$. vestitum 
Table 1. ANOVAs for the density of herbivorous amphipods sampled from 5 species of macroalgae during the day and night on 2 consecutive dates at Shark Bay. Algal host (Alga) and time of day (Day/Night) are fixed factors and sampling date (Date) is a random factor. Amphipod densities were $\ln$ transformed. ${ }^{*}$ Significant $F$-test

\begin{tabular}{|c|c|c|c|c|c|c|c|c|c|c|c|}
\hline & \multirow[t]{2}{*}{$\mathrm{df}$} & \multicolumn{2}{|c|}{ Ampithoe caddi } & \multicolumn{2}{|c|}{ A. kava } & \multicolumn{2}{|c|}{ A. ngana } & \multicolumn{2}{|c|}{ Exampithoe kutti } & \multicolumn{2}{|c|}{ Hyale nigra } \\
\hline & & $F$ & $\mathrm{p}$ & $F$ & $\mathrm{p}$ & $F$ & $\mathrm{p}$ & $F$ & $\mathrm{p}$ & $F$ & $\mathrm{p}$ \\
\hline Alga & 4 & 28.76 & $<0.01^{*}$ & 12.44 & $0.02^{*}$ & 56.92 & $<0.01^{*}$ & 81.59 & $<0.01^{*}$ & 4.78 & 0.08 \\
\hline Day/Night & 1 & 402.41 & $0.03^{*}$ & 19.09 & 0.14 & 7.97 & 0.22 & 2.52 & 0.36 & 0.23 & 0.72 \\
\hline Date & 1 & 1.42 & 0.24 & 4.22 & $0.04^{*}$ & 0.35 & 0.56 & 0.16 & 0.69 & 5.10 & $0.03^{*}$ \\
\hline Alga $\times$ Day/Night & 4 & 0.81 & 0.58 & 0.59 & 0.69 & 5.65 & 0.06 & 0.60 & 0.68 & 2.93 & 0.16 \\
\hline Alga $\times$ Date & 4 & 0.98 & 0.43 & 1.66 & 0.17 & 0.95 & 0.44 & 0.35 & 0.84 & 2.83 & $0.03^{*}$ \\
\hline Day/Night $\times$ Date & 1 & 0.01 & 0.92 & 0.08 & 0.78 & 0.21 & 0.65 & 0.34 & 0.56 & 2.66 & 0.11 \\
\hline Alga $\times$ Day/Night $\times$ Date & 4 & 2.86 & $0.03^{*}$ & 2.13 & 0.08 & 0.56 & 0.69 & 1.44 & 0.23 & 1.79 & 0.14 \\
\hline Error & 80 & & & & & & & & & & \\
\hline
\end{tabular}

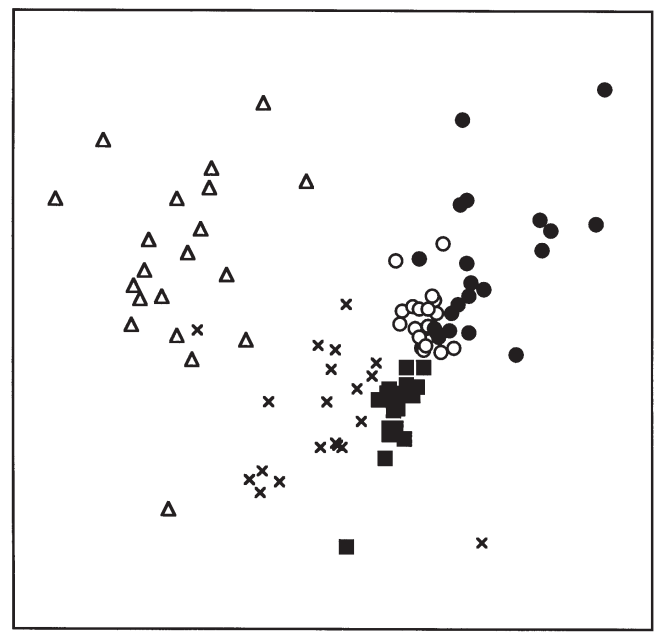

Fig. 2. MDS ordination of algal samples from the day-night sampling based on the composition of 8 species of herbivorous amphipods. MDS was conducted with amphipod numbers standardised to equal abundance per sample (stress = 0.19). Abbreviations for algal species as in Fig. 1

algal species (Fig. 2). The differences between algal species were highly significant (ANOSIM: $\mathrm{R}=0.70, \mathrm{p}<$ 0.001 , all pairwise comparisons with $\mathrm{p}<0.001$ ) while there were no significant differences between sampling times (ANOSIM: $\mathrm{R}=0.053, \mathrm{p}=0.06$ ).

\section{Long-term sampling of herbivorous amphipods}

The distribution patterns of the 3 species of herbivorous amphipods sampled over a longer time scale remained distinct over several months despite seasonal changes in the abundance of their host algae. Biancolina sp. was highly specialised, being found only on Sargassum linearifolium and $S$. vestitum throughout the year (Fig. 3a). Of the 1043 individuals collected, only 1 was sampled from any other host. Peramphithoe parmerong was found predominantly on

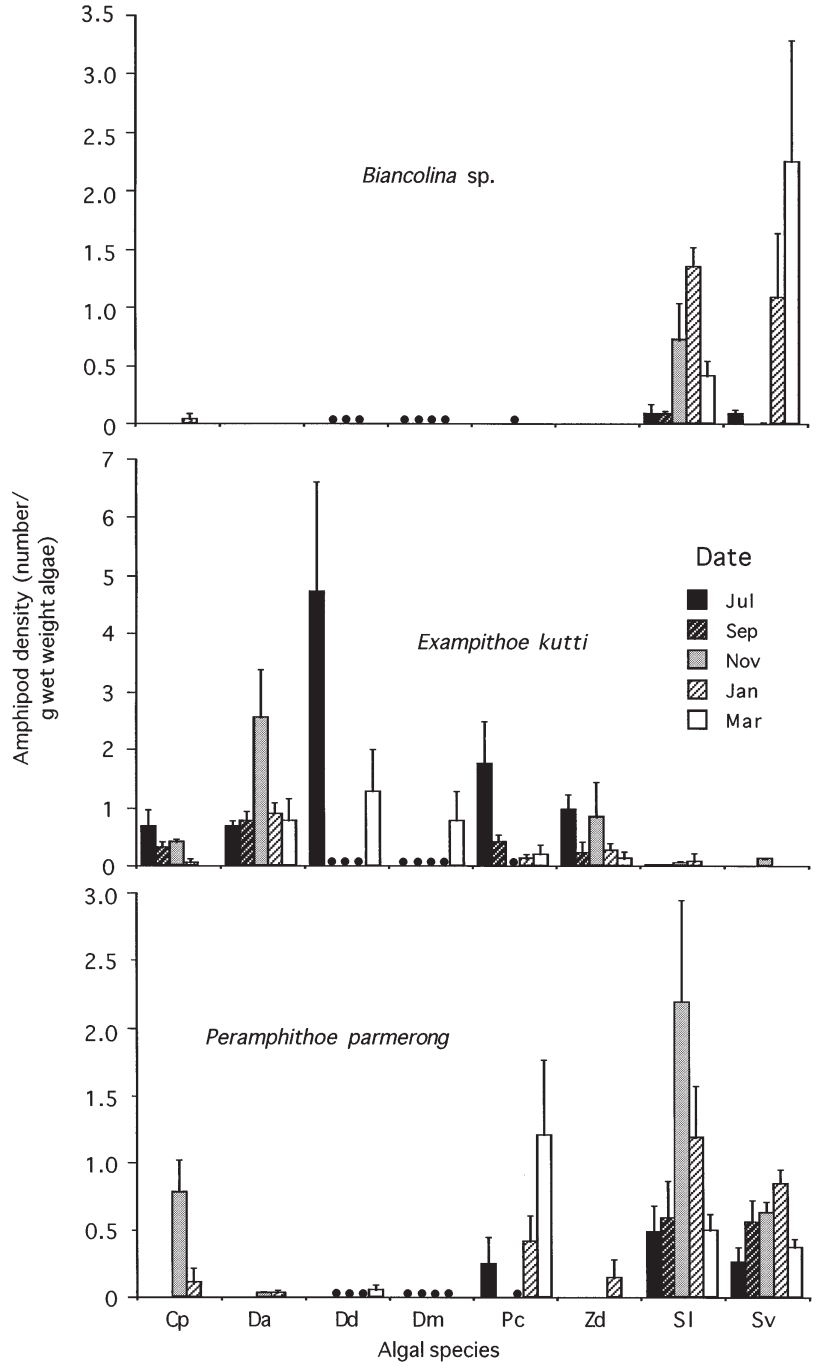

Fig. 3. Long-term sampling of the abundance of Biancolina sp., Exampithoe kutti and Peramphithoe parmerong on 8 species of brown algae at Shark Bay. Data are means $( \pm \mathrm{SE})$ of density (number per $\mathrm{g}$ wet weight of algae, $\mathrm{n}=5$ for each alga at each time). Abbreviations for algal species are as in Fig. 1, with additional species: Dd, Dictyota dichotoma; Dm, Dilophus marginatus; and $\mathrm{Pc}_{\mathrm{C}}$ Padina crassa. Dots above the $\mathrm{x}$-axis indicate that the alga was not present at Shark Bay during that sampling period 
the 2 species of Sargassum in all sampling months (Fig. 3c). In strong contrast to P. parmerong, Exampithoe kutti was largely absent throughout the year from the Sargassum spp. and had high densities on Dictyopteris acrostichoides, Dictyota dichotoma and Zonaria diesingiana (Fig. 3b).

\section{Effects of epiphytes on herbivorous amphipod distributions}

Densities of herbivorous amphipods were largely unaffected by variation in the epiphyte load on 2 abundant macroalgae, Dictyopteris acrostichoides and Sargassum linearifolium (Fig. 4). Epiphyte load had no significant effect on amphipod densities for all species considered except for Hyale nigra (Table 2). The densities of Biancolina sp. on both species could not be analysed using ANOVA as no individuals were found on $D$. acrostichoides. On $S$. linearifolium, however, densities did not differ significantly between fouled and clean plants (Student's $t$-test = 0.07, $\mathrm{p}=0.95$, df = 13).

In common with the day-night sampling, variation in amphipod densities was largely explained by algal species, with the differences between algae depending strongly on the amphipod species (Table 2). Sargassum linearifolium supported significantly higher densities of Peramphithoe parmerong and Biancolina sp. than Dictyopteris acrostichoides (Fig. 4e,f). In contrast, significantly higher densities of Ampithoe caddi and Exampithoe kutti were found on $D$. acrostichoides than on $S$. linearifolium (Fig. 4a,d). Densities of $A$. kava, A. ngana and Hyale nigra did not differ significantly between the 2 algal species (Fig. 4b,c,g).

As a result of the distribution patterns for individual amphipod species, the species composition of the amphipod fauna inhabiting both clean and fouled individuals of Dictyopteris acrostichoides and Sargassum linearifolium related strongly to algal species (Fig. 5). Based on amphipod numbers standardised for sample abundance, the differences between algal species were highly significant
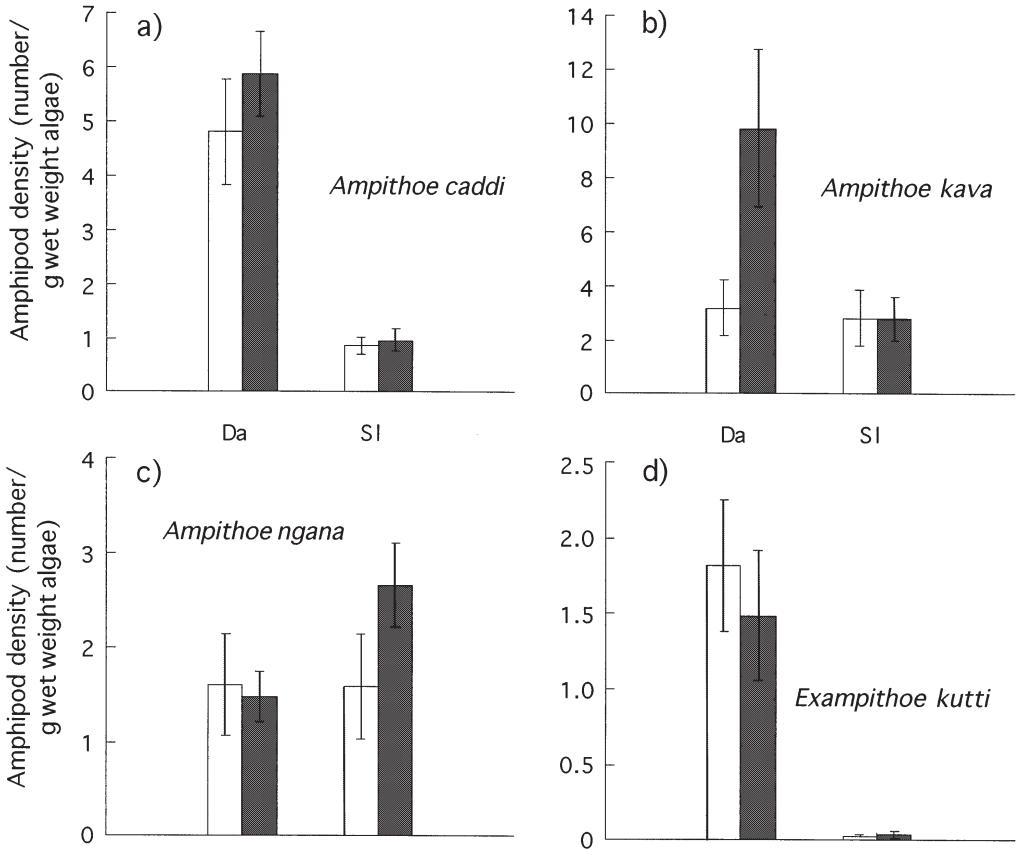

$\mathrm{Da}$

SI
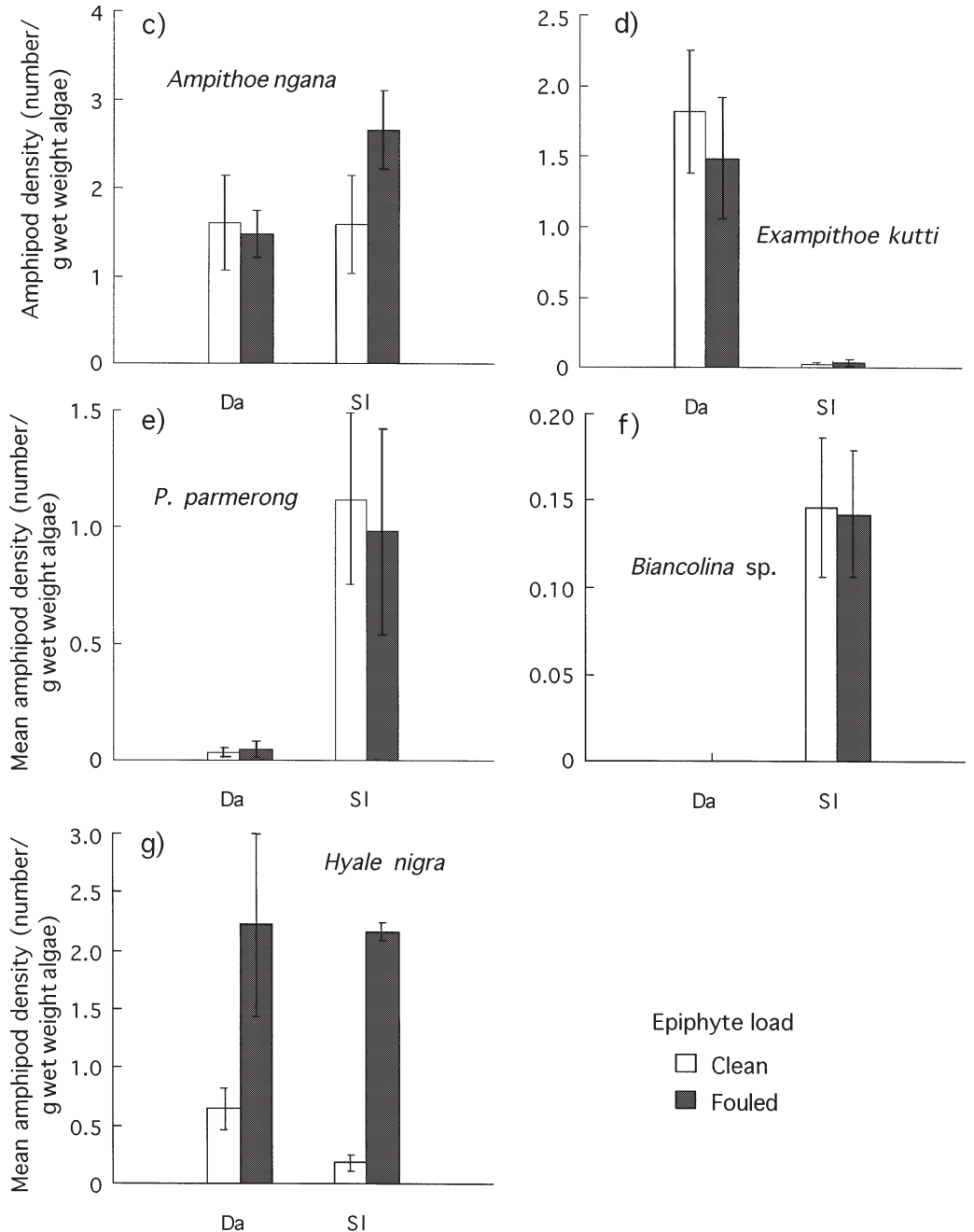

Epiphyte load

$\square$ Clean

Fouled

Fig. 4. Abundance of herbivorous amphipods on epiphyte-free and heavily fouled individuals of Sargassum linearifolium and Dictyopteris acrostichoides at Shark Bay. (a) Ampithoe caddi, (b) A. kava, (c) A. ngana, (d) Exampithoe kutti, (e) Peramphithoe parmerong, (f) Biancolina sp., and (g) Hyale nigra. Data are means $( \pm \mathrm{SE})$ of the number of amphipods per $g$ wet weight of algae ( $\mathrm{n}=8$ for each alga in each treatment)

(ANOSIM: $\mathrm{R}=0.98, \mathrm{p}<001$ ). Species composition also differed significantly between samples differing in epiphyte load (ANOSIM: $\mathrm{R}=0.11, \mathrm{p}=0.04$ ) presumably due to the differences in abundance of Hyale nigra. 
Table 2. ANOVAs for the density of herbivorous amphipods sampled from epiphyte-free and heavily fouled plants of both Dictyopteris acrostichoides and Sargassum linearifolium from Shark Bay. Epiphyte load and algal species are fixed factors. Amphipod densities were ln transformed except for those of Ampithoe caddi, which are square-root transformed. ${ }^{*}$ Significant $F$-test. Variance within the Exampithoe kutti and Peramphithoe parmerong data sets is highly heterogeneous due to the low amphipod densities, and correspondingly low variance, on $S$. linearifolium (for E. kutti) or D. acrostichoides (for P. parmerong); however, since heterogeneous variance increases the probablity of a type I error, the non-significant results of epiphyte load are robust to this violation of ANOVA's assumptions (Underwood 1997)

\begin{tabular}{|c|c|c|c|c|c|c|c|c|c|c|c|c|c|}
\hline & \multirow[t]{2}{*}{$\mathrm{df}$} & \multicolumn{2}{|c|}{ A. caddi } & \multicolumn{2}{|c|}{ A. kava } & \multicolumn{2}{|c|}{ A. ngana } & \multicolumn{2}{|c|}{ E. kutti } & \multicolumn{2}{|c|}{ P. parrmerong } & \multicolumn{2}{|c|}{ H. nigra } \\
\hline & & $F$ & $\mathrm{p}$ & $F$ & $\mathrm{p}$ & $F$ & $\mathrm{p}$ & $F$ & $\mathrm{p}$ & $F$ & $\mathrm{p}$ & $F$ & $\mathrm{p}$ \\
\hline Algal species & 1 & 76.49 & $<0.01^{*}$ & 3.51 & 0.07 & 0.61 & 0.44 & 95.87 & $<0.01^{*}$ & 22.31 & $<0.01^{*}$ & 3.88 & 0.06 \\
\hline Epiphyte load & 1 & 0.85 & 0.37 & 2.25 & 0.15 & 2.36 & 0.14 & 1.02 & 0.32 & 0.24 & 0.63 & 16.44 & $<0.01^{*}$ \\
\hline $\begin{array}{r}\text { Algal species } \times \\
\text { Epiphyte load }\end{array}$ & 1 & 0.6 & 0.45 & 1.60 & 0.22 & 0.85 & 0.37 & 0.88 & 0.34 & 0.33 & 0.57 & 1.07 & 0.31 \\
\hline Error & 27 & & & & & & & & & & & & \\
\hline
\end{tabular}

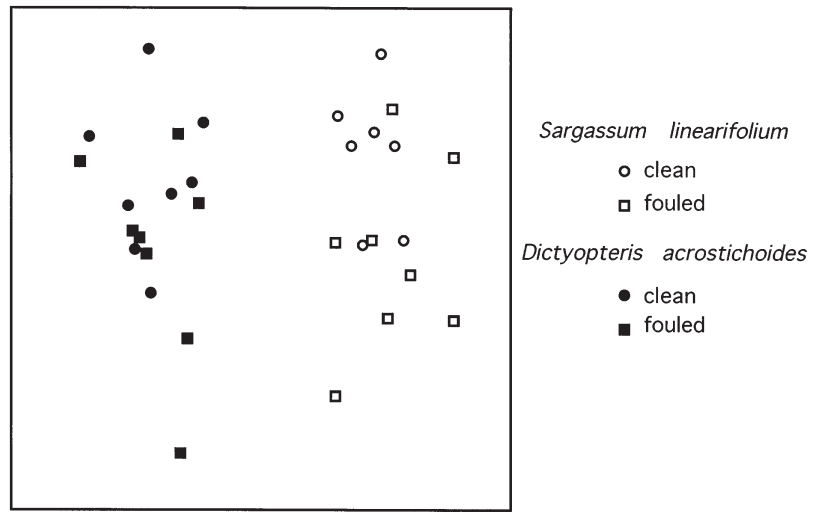

Fig. 5. MDS ordination of species composition of 7 species of herbivorous amphipods on epiphyte-free and heavily fouled individuals of Sargassum linearifolium and Dictyopteris acrostichoides. MDS was conducted with amphipod numbers standardised to equal abundance per sample $($ stress $=0.08)$

\section{Abundance of amphipods on sponge and coral hosts}

A diverse amphipod fauna (56 species) was associated with sponge hosts at Bare Island. The most common amphipod families collected were the Icilidae (36\% of the total number of individuals collected), Leucothoidae $(28 \%)$, Colomastigidae $(6 \%)$ and Eusiridae $(4 \%)$. The 6 most abundant species (in decreasing order of mean density across all hosts) were Icilius australis Haswell, Ausatelson sp., Sancho platynotus Stebbing, Leucothoella sp., Leucothoe sp. and Yulumara sp. (Fig. 6). The soft coral Capnella gaboensis also supported high densities of amphipods, dominated by Ausatelson sp. in the family Stenothoidae (19\% of the total number of individuals collected).

Sponge- and coral-associated amphipod species also displayed uneven distribution patterns across hosts. Levels of host specificity were higher than among herbivores on algae, with abundant amphipod species often restricted to 1 or a few host species. The most abundant amphipod, Icilius australis, was widespread and occurred at the highest densities on Phorbas sp. and Antho chartacea (Fig. 6a). Sancho platynotus was largely restricted to Holopsamma laminaefavosa, a sponge that supported few I. australis (Fig. 6a). Ausatelson sp. was restricted to the soft coral Capnella gaboensis, on which it was highly abundant (Fig. 6a). In the family Leucothoidae, Leucothoella sp. occurred only on Callyspongia sp. 1, while Leucothoe sp. was most abundant on Iotrochopsamma arbuscula (Fig. 6b). Yulumara sp. was abundant on $H$. laminaefavosa and occurred sporadically on other hosts (Fig. 6b).

The strong patterns of distribution across sponge species for individual amphipod species resulted in a characteristic species composition of amphipods on each sponge species. Even though the MDS plot (Fig. 7, based on amphipod numbers standardised for sample abundance) is a poor 2-dimensional representation of the relationships between samples (stress = 0.22), samples are still mostly grouped according to host species. The differences between host species were highly significant (ANOSIM: $\mathrm{R}=0.525$, $\mathrm{p}<001$, all pairwise comparisons with $\mathrm{p}<0.001$ ).

\section{DISCUSSION}

\section{Distribution patterns of amphipods on algal and sponge hosts}

Individual species of amphipods in this study exhibited a mixture of host ranges on algal and sponge hosts, from relatively generalised (e.g., Ampithoe spp., Icilius australis) to more specialised species (e.g., Exampithoe kutti and Peramphithoe parmerong), with a few (Biancolina sp. and Plumithoe quadrimana) being restricted to 1 species or genus of host sampled. For herbivorous amphipods, this diversity of feeding 
habits is similar to previous studies (Duffy \& Hay 1994), although we did record a relatively high proportion of somewhat specialised species. The most specialised herbivore in this study in terms of host and feeding habit was the burrowing Biancolina sp., which was restricted to feeding on Sargassum spp. This species represents one of the rare cases of strong feeding specialisation among marine herbivores. Interestingly, several other examples of marine specialists are also herbivores that feed from within plant tissues, including the amphipod Pseudamphithoides incurvaria (Hay et al. 1990) and the leaf-mining isopods in the genus Lynseia (Brearley \& Walker 1995). Invertebrates that live in close association with their hosts (e.g., internal parasites) are usually more specialised than those with less intimate associations (Price 1980). These findings for marine herbivores are consistent with those found for terrestrial insects, in which species that feed internally tend to be more specialised than those that feed externally (Gaston et al. 1992). Although marine leaf- or stem-miners are rare relative to terrestrial environments (Hay \& Steinberg 1992), burrowing species are found within several amphipod (Conlan \& Chess 1992), isopod (Brearley \& Walker 1995), copepod (Ho \& Hong 1988) and polychaete (Guidetti et al. 1997) families. Further investigation of the feeding ecology of these groups may reveal more specialist herbivores.

Amphipods associated with sponges also varied in the extent of their specialisation across hosts, with some species again being relatively specialised. Comparison with previous research is more difficult than for herbivorous species, as there are few quantitative data on amphipods associated with sponges or other invertebrates (Thiel 1999). It is not known whether the high levels of host specificity recorded here for such species as Leucothoella sp. or Ausatelson sp. are unusual. We would expect sponge-associated amphipods, many of which live within sponge tissue, to be more specialised, on average, than amphipods associated with algae if the pattern of host specificity relative to feeding mode observed in plants also applies to invertebrate hosts. Other invertebrates that live within sponge tissue may be highly host specific (e.g., the shrimp
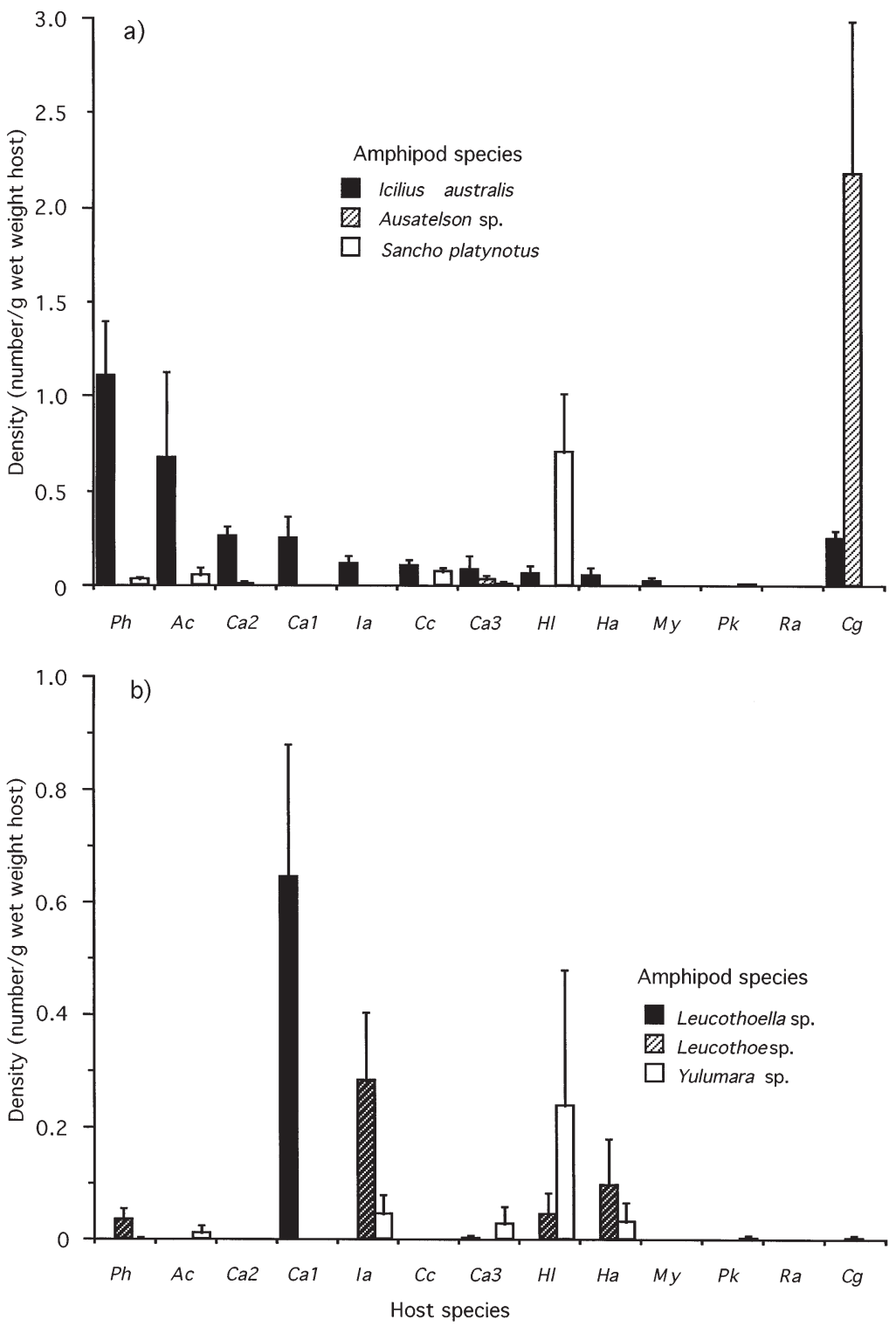

Fig. 6. Densities of the 6 most abundant amphipod species associated with 12 sponge species and 1 soft coral at Bare Island. (a) Icilius australis, Austratelson sp. and Sancho platynotus, (b) Leucothoella sp., Leucothoe sp. and Yulumara sp. Data are means $( \pm \mathrm{SE}$ ) of density (number per $g$ wet weight of host, $\mathrm{n}=5$ for each host; note that the scale of the $y$-axis between (a) and (b) differs). Sponge species are sorted in decreasing order of abundance of Icilius australis. Abbreviations for sponge species are: $\mathrm{Ph}$, Phorbas sp.; Ac, Antho (Isopenectya) chartacea; Ca2, Callyspongia sp. 2; Ca1, Callyspongia sp. 1; Ia, Iotrochopsamma arbuscula; Cc, Cymbastella concentrica; Ca3, Callyspongia sp. 3; Hl, Holopsamma laminaefavosa; Ha, Halichondria sp.; My, Mycale (Carmia) sp.; Pk, Phoriospongia cf. kirki; Ra, Raphoxya sp.; Cg, soft coral Capnella gaboensis

genus Synalpheus, Duffy 1996a), suggesting that this system provides an excellent opportunity to test hypotheses relating to host range in marine invertebrates.

While true specialisation of individual amphipod species was uncommon, from the perspective of the 


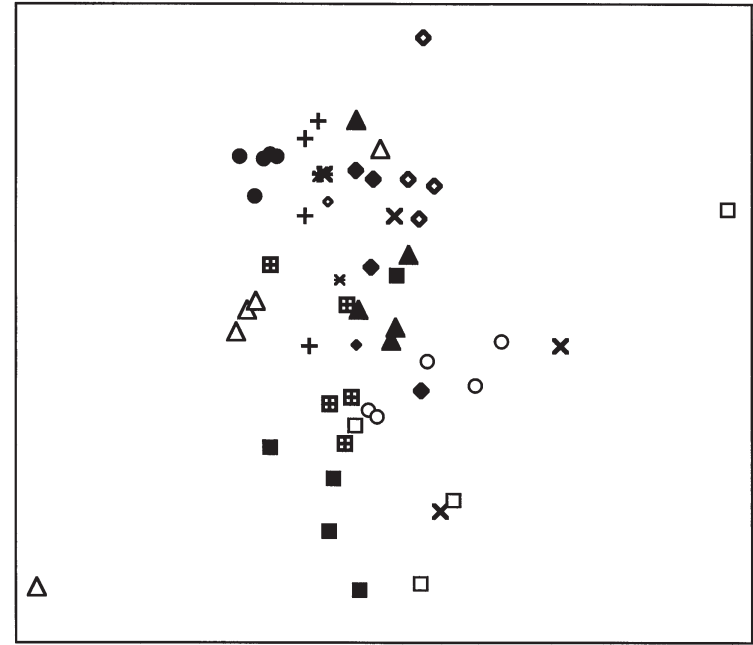

Host species

O HI

- $A c$

* My

- la

- $\mathrm{Ha}$

口 $\mathrm{Pk}$

$\Delta \mathrm{Ca} 1$

$\Delta \mathrm{Ph}$

$\times \mathrm{Ca} 3$

$+\mathrm{Ca} 2$

田 $\mathrm{Cc}$

- $\mathrm{Cg}$

Fig. 7. MDS ordination of sponge samples based on the composition of 56 species of amphipods associated with 11 sponge species and 1 soft coral, Capnella gaboensis. MDS was conducted with amphipod numbers standardised to equal abundance per sample (stress $=0.22$ ). Abbreviations as in Fig. 6

hosts the disjunct distributions of individual amphipod species resulted in distinct assemblages of amphipods associated with host algae or sponges (or the soft coral Capnella) (Figs. 2, 5 \& 7). For the algae, these patterns were largely consistent with respect to the time of sampling (day vs night) and remained distinctive across different seasons and in the presence of heavy epiphyte cover. They were also independent of host abundance. Exampithoe kutti was very abundant on the rare Dictyota dichotoma, Plumithoe quadrimana was most abundant on the relatively uncommon Colpomenia peregrina, and several amphipods were rare on Sargassum vestitum, the most abundant algal species sampled at Shark Bay (Poore \& Steinberg 1999). Biancolina sp., E. kutti and Peramphithoe parmerong remained on a restricted set of species throughout the year despite large temporal fluctuations in the availability of host algae (Poore \& Steinberg 1999). Similarly, for the sponge-associated amphipods, abundance was not simply related to sponge availability (Watson unpubl. data).

It is interesting that this pattern of host-specific amphipod assemblages held true both for herbivorous amphipods on algae, where host specificity relates to feeding specificity, and for amphipods on sponges, where host specificity most likely related to habitat specificity. This pattern of distinct host-associated assemblages stands in strong contrast to most previous analogous studies, which have typically found differences in abundance among hosts, but few differences in species composition for amphipod assemblages from either algal (e.g., Edgar 1983a, Lewis 1987), seagrass (e.g., Stoner 1983, Virnstein \& Howard 1987) or sponge (e.g., Biernbaum 1981, Costello \& Myers 1987) hosts. One likely reason for these differences for alga-associated amphipods is that many previous studies analysed the entire amphipod fauna, rather than strictly herbivorous species as was studied here. This would have confounded amphipods associating with the algae due to habitat selection versus feeding choice, as well as being more likely to include transient individuals (or species) with those that had actively selected the host.

Contrasting our findings of differences in amphipod species composition among sponges and a soft coral with previous studies is difficult due to the limited data base for comparison. To our knowledge, only 4 studies have quantitatively compared the amphipod fauna from different sponge species and these all dealt with few host species. Costello \& Myers (1987) contrasted the amphipod fauna of the sponges Halichondria panicea and Hymeniacidon perleve and found little difference in amphipod species composition. Biernbaum (1981) compared the amphipod fauna on 4 species of estuarine sponges and found that, while densities varied, species composition was largely consistent. However, Koukouras et al. $(1992,1996)$ found differences in amphipod species composition on several sponge species with differing morphology.

The soft coral Capnella gaboensis also supported a distinctive amphipod fauna, dominated by the stenothoid Ausatelson sp. Stenothoids are predominantly found on cnidaridans, but also occur on algae and other invertebrate substrates (Vader \& Krapp-Shickel 1996). It is perhaps not surprising that amphipods inhabiting this host differed from those on sponges, due to the many differences between corals and sponges. There was, however, some overlap between the amphipod fauna on both host groups, and some of the amphipod families associated with cnidarians are also commonly associated with sponges (Vader 1983, 1984).

\section{Possible mechanisms for the observed patterns of distributions}

Three hypotheses seem most relevant as possible explanations for the distribution of amphipods on hosts found here: (1) Factors extrinsic to the host, in particular differential predation of amphipods on different hosts, determine amphipod distributions; (2) Individual species of amphipods are distributing themselves inde- 
pendently of one another due to species-specific preferences for intrinsic qualities of the hosts as food or habitat; and (3) Amphipod distributions are affected by interspecific competition.

Of these 3 hypotheses, the first 2 have received the most attention in the literature. Predation has been invoked as an important influence on host range for both terrestrial and marine herbivores, and it has been argued that specialisation is more likely among small herbivores that use hosts as a means of escaping predation (Bernays \& Graham 1988, Hay \& Steinberg 1992). In a proximate sense, we consider it unlikely that amphipod distributions in this study are determined by differential predation across hosts by fishes or other predators or omnivores. The almost non-overlapping distributions of Peramphithoe parmerong and Exampithoe kutti, 2 similarly sized amphipods with identical life styles, would arise from differential predation only if fish consumed E. kutti but not $P$. parmerong on the 'preferred' hosts for P. parmerong, and the converse on hosts for E. kutti. While fish do display preferential feeding among some amphipod species (Nelson 1979, Stoner 1979), we know of no evidence that preferences reverse on different host plants (as would have to occur many times for multiple species in order to explain the patterns observed here). From an evolutionary perspective, Duffy \& Hay (1991b) argue that while amphipod distributions are rarely determined proximately by differential mortality (active habitat selection is more important), predation is the ultimate factor influencing host plant range. If this were the case for these amphipods, each species must have evolved their preferences under different predation regimes than are currently present.

Chemical traits of the hosts may also affect the susceptibility of amphipods to predation, and predation on small herbivores may be reduced due to their association with chemically rich hosts that are avoided by omnivorous fish (reviewed in Hay \& Steinberg 1992). In our system, there appears to be no simple relationship between palatability of algae to local herbivorous fish and amphipod distributions (see Poore \& Steinberg 1999 for discussion). Similarly, amphipod distributions may be negatively correlated (Peramphithoe parmerong, Biancolina sp.), positively correlated (EXampithoe kutti) or unrelated (Ampithoe spp.) to the presence of non-polar secondary metabolites in the algae sampled. Secondary compounds from sponges may also affect the likelihood of host consumption by generalist predators (Wright et al. 1997); however, the relative susceptibility to predation of amphipods associated with chemically defended sponges remains untested.

The second hypothesis - the role of intrinsic host factors - has been widely discussed, with an emphasis on chemical traits (e.g., secondary chemistry) and habitat complexity of the hosts. Poore \& Steinberg (1999) showed the importance of intrinsic host plant qualities for Peramphithoe parmerong. In that species, host qualities, particularly the presence of non-polar secondary metabolites, affected amphipod preferences and field distributions. The algae containing non-polar secondary metabolites that are avoided by $P$. parmerong, however, do support large populations of herbivorous amphipods that readily consume their hosts, supporting the view that responses of amphipods to secondary compounds are species specific (Duffy \& Hay 1991a, 1994)

The diet of amphipods associated with sponges and other benthic invertebrates is poorly known and it was not possible to readily identify, by taxonomic group or morphology, species that may feed on sponge tissue (Vader 1984). Amphipods that do consume sponge tissue (e.g., Paramphithoe hystrix, Oshel \& Steele 1985) differ little in morphology from closely related species that feed on external food sources. The role of sponge qualities on amphipod host use is similarly poorly known; however, secondary metabolites may correlate with numbers of associated invertebrates (BetancourtLozano et al. 1998) and affect amphipod behaviour (Frith 1977). In this study, sponges from genera known to produce biologically active secondary compounds (e.g., Callyspongia, Halichondria) did support high densities of some species of amphipods. However, given the disjunct distributions of amphipod species, these compounds cannot be generally deterrent (or attractive) to all associated amphipods.

In general, increased structural complexity of hosts provides increased protection for small marine invertebrates (Nelson 1979, Stoner 1979), and amphipods are often (e.g., Hacker \& Steneck 1990) but not always (e.g., Lewis 1987, Holmlund et al. 1990) more abundant on complex plant hosts. For the herbivorous amphipods sampled here, there was no simple relationship between structural complexity and abundance. A morphologically simple species such as Colpomenia peregrina supported more Plumithoe quadrimana than any other host, while the highly branched alga Sargassum linearifolium was avoided by Exampithoe kutti. Similarly for sponge hosts, there seemed no clear pattern between sponge morphology and amphipod abundance (e.g., the morphologically simple Callyspongia sp. 1 supporting the highest densities of Leucothoella sp.).

Finally, for amphipods from Sargassum linearifolium and Dictyopteris acrostichoides, species abundance and composition were largely unrelated to the abundance of epiphytes. The abundance of only 1 species, Hyale nigra, was positively correlated with epiphyte load. Amphipod abundances can be corre- 
lated with epiphyte loads (Bell 1991) although the correlations, as with distributions across hosts, are species specific (Schneider \& Mann 1991). The maintenance of distinct amphipod assemblages on each host even in the presence of high epiphyte loads contrasts with previous studies that have shown epiphyte loads to mask differences between hosts (Edgar 1983b, Johnson \& Scheibling 1987). One explanation for the difference in our results and some previous studies is that the effects of epiphytes on amphipods are likely to differ between algal systems, where both host and epiphytes are potentially edible and taxonomically similar, and seagrass systems, in which the host is rarely consumed by amphipods (Poore \& Steinberg 1999).

The third hypothesis is that amphipod-amphipod interactions generate these disjunct patterns. Negative correlations between the distribution of similar species, such as that found for Peramphithoe parmerong and Exampithoe kutti, have been interpreted as initial evidence for interspecific competition in many systems. The view that competition among small invertebrate herbivores is unimportant (Futuyma \& Moreno 1988) is now being challenged in the light of recent interest in competition as a structuring force for insects on terrestrial plants (Denno et al. 1995). Marine epifaunal assemblages have been shown to be food limited in both algal (Edgar \& Aoki 1993) and seagrass (Edgar 1990) systems, and negative correlations between species distributions have been previously recorded among ampithoid (Gunnill 1984) and hyalid (Lancellotti \& Trucco 1993) amphipods. Negative correlations between species distributions, however, are only suggestive of competition, and the influence of competition on marine mesoherbivores is poorly understood. In contrast to the above studies, others have found little evidence for competition among epifaunal amphipods based on distributional data and laboratory experiments (Nelson 1979, Stoner 1985, Duffy \& Hay 1991b). Similar analyses have not been reported for sponge-associated amphipods, but competition has been invoked as an important determinant of host use in other spongedwelling invertebrates (e.g, the sponge shrimps Synalpheus, Duffy 1996a,b).

Competitive interactions may result from exploitation of limited shared resources, or interference due to behavioural interactions. While amphipod assemblages have been shown to be limited by the production of epiphytes (Edgar 1990, Edgar \& Aoki 1993), the degree to which amphipods that consume their hosts, rather than epiphytes, are food limited remains untested. The abundance of host tissue relative to consumption rates, and the fact that herbivorous amphipods have rarely been shown to have significant effects on host macroalgae, would suggest that exploitation competition among amphipods is rare. Similar arguments can be made for sponge-associated amphipods. Strong preferences for certain parts of a host, such as new growth (Poore 1994) or reproductive tissue (Buschmann \& Santelices 1987), however, may lead to highly preferred food resources becoming limited while other tissues remain in excess.

Even without food being limited for amphipod herbivores of macroalgae or commensals of sponges, negative interactions may still occur through interference competition, with aggressive interactions affecting species distributions. Herbivorous amphipods can be aggressive toward one another and may maintain territories. In a coral reef mesocosm, Brawley \& Adey (1981) showed that the distribution of tubes built by Ampithoe ramondi became evenly spaced, and aggressive interactions became more frequent, as amphipod densities increased. Nagle (1968) demonstrated that the amphipods Microdeutops damnoniensis and Corophium acutum, which had inhabited different parts of the seagrass Zostera marina, would physically displace one another when placed in the same habitat. Gunnill (1984) suggested that aggression by Peramphithoe tea may limit the distribution of other ampithoid species on the brown alga Pelvetia fastigata. We are aware of no similar behavioural observations of aggression among sponge-associated amphipods, but aggressive interactions are commonplace among sponge-dwelling shrimps (Duffy 1996c).

\section{Conclusions}

In contrast to most previous studies, the herbivorous amphipods associated with algae, and the commensal amphipods associated with sponges, studied here occurred as distinct assemblages among different host species. For species associated with macroalgae, the difference between our results and previous work may be due to our focus on herbivorous species only. However, similar patterns were also observed on sponges, where host specificity most likely relates to habitat specificity only. Also, in contrast to a number of studies, we found that the distribution of herbivorous amphipods on macroalgae was mostly unaffected by variation in the abundance of epiphytes. The disjunct distribution of species across hosts is consistent with competition playing a role as a structuring force in these communities. Whatever the mechanism structuring these communities, the species-specific responses of amphipods to the identity of potential hosts confirm the view that herbivorous amphipods cannot be treated as a homogeneous group (Duffy \& Hay 1991a, 1994). 
Acknowledgements. We thank Sharon Longford for assistance in the field, John Hooper (Queensland Museum) for sponge identification, and Emmett Duffy and an anonymous reviewer for suggestions that improved this manuscript. A.G.B.P. was supported during the period of this work by an Australian Postgraduate Award. Support for this research came from an Australian Research Council Large Grant to P.D.S.

\section{LITERATURE CITED}

Barnard JL (1974) Gammaridean amphipoda of Australia. Part II. Smithson Contrib Zool 139:1-148

Bell SS (1991) Amphipods as insect equivalents? An alternative view. Ecology 72:350-354

Bernays EA, Chapman RF (1994) Host-plant selection by phytophagous insects. Chapman \& Hall, New York

Bernays E, Graham M (1988) On the evolution of host specificity in phytophagous arthropods. Ecology 69:886-892

Betancourt-Lozano M, González-Farias F, González-Acosta B, García-Gasca A, Bastida-Zavala JR (1998) Variation of antimicrobial activity of the sponge Aplysina fistularis (Pallas, 1766) and its relation to associated fauna. J Exp Mar Biol Ecol 223:1-18

Biernbaum CK (1981) Seasonal changes in the amphipod fauna of Microciona prolifera (Ellis and Solander) (Porifera: Demospongia) and associated sponges in a shallow salt-marsh creek. Estuaries 4:85-96

Blunt J, Munro M (1998) Marinlit electronic database. University of Canterbury, Christchurch

Brawley SH (1992) Mesoherbivores. In: John DM, Hawkins SJ, Price JH (eds) Plant-animal interactions in the marine benthos. Clarendon Press, Oxford, p 235-263

Brawley SH, Adey WH (1981) The effect of micrograzers on algal community structure in a coral reef microcosm. Mar Biol 61:167-177

Brearley A, Walker D (1995) Isopod miners in the leaves of two Western Australian Posidonia species. Aquat Bot 52: 163-181

Buschmann AH, Santelices B (1987) Micrograzers and spore release in Iridaea laminarioides Bory (Rhodophyta: Gigartinales). J Exp Mar Biol Ecol 108:171-179

Clarke KR, Warwick RM (1994) Change in marine communities: an approach to statistical analysis and interpretation. Plymouth Marine Laboratory, Plymouth

Conlan KE, Chess JR (1992) Phylogeny and ecology of a kelpboring amphipod, Peramphithoe stypotrupetes, new species (Corophioidea: Ampithoidae). J Crustac Biol 12: 410-422

Costello MJ, Myers AA (1987) Amphipod fauna of the sponges Halichondria panicea and Hymeniacidon perleve in Lough Hyne, Ireland. Mar Ecol Prog Ser 41:115-121

Denno RF, McClure MS, Ott JR (1995) Interspecific interactions in phytophagous insects: competition re-examined and resurrected. Annu Rev Entomol 40:297-331

Duffy JE (1996a) Species boundaries, specialization, and the radiation of sponge-dwelling alpheid shrimp. Biol J Linn Soc 58:307-324

Duffy JE (1996b) Synalpheus regalis, new species, a sponge dwelling shrimp from the Belize Barrier Reef, with comments on host specificity in Synalpheus. J Crustac Biol 16: 564-573

Duffy JE (1996c) Eusociality in a coral-reef shrimp. Nature 381:512-514

Duffy JE, Hay ME (1991a) Amphipods are not all created equal: a reply to Bell. Ecology 72:354-358
Duffy JE, Hay ME (1991b) Food and shelter as determinants of food choice by an herbivorous marine amphipod. Ecology 72:1286-1298

Duffy JE, Hay ME (1994) Herbivore resistance to seaweed chemical defense: the roles of mobility and predation risk. Ecology 75:1304-1319

Edgar GJ (1983a) The ecology of south-eastern Tasmanian phytal animal communities. I. Spatial organisation on a local scale. J Exp Mar Biol Ecol 70:129-157

Edgar GJ (1983b) The ecology of south-eastern Tasmanian phytal animal communities. II. Seasonal changes in plant and animal populations. J Exp Mar Biol Ecol 70:159-179

Edgar GJ (1990) Population regulation, population dynamics and competition amongst mobile epifauna associated with seagrass. J Exp Mar Biol Ecol 144:205-234

Edgar GJ, Aoki M (1993) Resource limitation and fish predation: their importance to mobile epifauna associated with Japanese Sargassum. Oecologia 95:122-133

Farrant PA, King RJ (1989) The Dictyotales (Algae: Phaeophyta) of New South Wales. Proc Linn Soc NSW 110: 369-405

Faulkner (1998) Marine natural products. Nat Prod Rep 15: 113-158

Frith DW (1977) A preliminary analysis of the association of amphipods Microdeutopus damnoniensis (Bate), $M$. anomalus (Rathke) and Corophium sextoni Crawford with sponges Halichondria panicea (Pallas) and Hymeniacidon perleve (Montagu). Crustaceana 32:113-118

Futuyma DJ, Moreno G (1988) The evolution of ecological specialization. Annu Rev Ecol Syst 19:207-233

Gaston KJ, Reavey D, Valladares, GR (1992) Intimacy and fidelity - internal and external feeding by the British microlepidoptera. Ecol Entomol 17:86-88

Guidetti P, Bussotti S, Gambi MC, Lorenti M (1997) Invertebrate borers in Posidonia oceanica scales: relationship between their distribution and lepidochronological parameters. Aquat Bot 58:151

Gunnill FC (1984) Differing distributions of potentially competing amphipods, copepods and gastropods among specimens of the intertidal alga Pelvetia fastigata. Mar Biol 82:277-291

Hacker SD, Steneck RS (1990) Habitat architecture and the abundance and body-size-dependent habitat selection of a phytal amphipod. Ecology 71:2269-2285

Hay ME, Steinberg PD (1992) The chemical ecology of plantherbivore interactions in marine versus terrestrial communities. In: Rosenthal GA, Berembaum M (eds) Herbivores: their interaction with secondary plant metabolites, Vol 2, Ecological and evolutionary processes. Academic Press, San Diego, p 371-413

Hay ME, Duffy JE, Fenical W (1990) Host-plant specialization decreases predation on a marine amphipod: an herbivore in plant's clothing. Ecology 71:733-743

Ho JS, Hong JS (1988) Harpacticoid copepods (Thalestridae) infesting the cultivated Wakame (brown alga, Undaria pinnatifida) in Korea. J Nat Hist 22:1623-1637

Holmlund MB, Peterson CH, Hay ME (1990) Does algal morphology affect amphipod susceptibility to fish predation? J Exp Mar Biol Ecol 139:65-83

Ishimaru S (1996) Taxonomic review of the family Biancolinidae (Amphipoda: Gammaridea), with description of a new species from Japan. J Crustac Biol 16:395-405

Jaenike J (1990) Host specialization in phytophagous insects. Annu Rev Ecol Sys 21:243-273

Jensen KR (1997) Evolution of the Sacoglossa (Mollusca, Opisthobranchia) and the ecological associations with their food plants. Evol Ecol 11:301-335 
Johnson SC, Scheibling RE (1987) Structure and dynamics of epifaunal assemblages on intertidal macroalgae Ascophyllum nodosum and Fucus vesiculosus in Nova Scotia, Canada. Mar Ecol Prog Ser 37:209-227

Koukouras A, Russo A, Voultsiadou-Koukoura E, Dounas C, Chintiroglou C (1992) Relationship of sponge macrofauna with morphology of their hosts in the North Aegean Sea. Int Rev Ges Hydrobiol 77:609-619

Koukouras A, Russo A, Voultsiadou-Koukoura E, Arvanitidis C, Stefenidou D (1996) Macrofauna associated with sponge species of different morphology. PSZN I: Mar Ecol 17:569-582

Lancellotti DA, Trucco RG (1993) Distribution patterns and coexistence of six species of the amphipod genus Hyale. Mar Ecol Prog Ser 93:131-141

Lewis FG III (1987) Crustacean epifauna of seagrass and macroalgae in Apalachee Bay, Florida, USA. Mar Biol 94: $219-229$

Nagle JS (1968) Distribution of the epibiota of macroepibenthic plants. Contrib Mar Sci 13:105-144

Nelson WG (1979) Experimental studies of selective predation on amphipods: consequences for amphipod distribution and abundance. J Exp Mar Biol Ecol 38:225-245

Oshel PE, Steele DH (1985) Amphipod Paramphithoe hystrix: a micropredator on the sponge Halicona ventilabrum. Mar Ecol Prog Ser 23:307-309

Poore AGB (1994) Selective herbivory by amphipods inhabiting the brown alga Zonaria angustata. Mar Ecol Prog Ser 107:113-122

Poore AGB, Lowry JK (1997) New ampithoid amphipods from Port Jackson, New South Wales, Australia (Crustacea: Amphipoda: Ampithoidae). Invertebr Taxon 11:897-941

Poore AGB, Steinberg PD (1999) Preference-performance relationships and effects of host plant choice in a herbivorous marine amphipod. Ecol Monogr 69:443-464

Price PW (1980) Evolutionary biology of parasites. Princeton University Press, Princeton

Rowntree VJ (1996) Feeding, distribution, and reproductive behavior of cyamids (Crustacea, Amphipoda) living on humpback and right whales. Can J Zool 74:103-109

Schneider FI, Mann KH (1991) Species specific relationships to vegetation in a seagrass bed. II. Experiments on the importance of macrophyte shape, epiphyte cover and predation. J Exp Mar Biol Ecol 145:119-139

Sotka EE, Hay ME, Thomas JD (1999) Host-plant specialization by a non-herbivorous amphipod: advantages for the

Editorial responsibility: Joseph Pawlik, Wilmington, North Carolina, USA amphipod and costs for the seaweed. Oecologia 118: 471-482

Stoner AW (1979) Species-specific predation on amphipod crustacea by the pinfish Lagodon rhomboides: mediation by macrophyte standing crop. Mar Biol 55:201-207

Stoner AW (1983) Distributional ecology of amphipods and tanaidaceans associated with three sea grass species. J Crustac Biol 3:505-518

Stoner AW (1985) Penicillus capitatus: an algal island for macrocrustaceans. Mar Ecol Prog Ser 26:279-287

Thiel M (1999) Host-use and population dynamics of the ascidian-dwelling amphipod Leucothoe spinicarpa: indication for extended parental care and advanced social behaviour. J Nat Hist 33:193-206

Thompson JN (1994) The coevolutionary process. The University of Chicago Press, Chicago

Underwood AJ (1997) Experiments in ecology: their logical design and interpretation using analysis of variance. Cambridge University Press, Cambridge

Vader W (1972) Associations between amphipods and molluscs. A review of published records. Sarsia 48:13-18

Vader W (1978) Associations between amphipods and echinoderms. Astarte 2:123-134

Vader W (1983) Associations between amphipods (Crustacea: Amphipoda) and sea anemones (Anthozoa, Actinaria). Aust Mus Mem 18:141-153

Vader W (1984) Notes on Norwegian marine Amphipoda. 8. Amphipods found in association with sponges and tunicates. Fauna Norv Ser A 5:16-21

Vader W, Krapp-Shickel G (1996) Redescription and biology of Stenothoe brevicornis Sars (Amphipoda: Crustacea), an obligate associate of the sea anemone Actinostola callosa (Verrill). J Nat Hist 30:51-66

Virnstein RW, Howard RK (1987) Motile epifauna of marine macrophytes in the Indian River Lagoon, Florida. I. Comparisons among three species of seagrasses from adjacent beds. Bull Mar Sci 41:1-12

Wilkinson L (1990) SYSTAT: the system for statistics. SYSTAT Inc, Evanston, IL

Womersley HBS (1987) The marine benthic flora of southern Australia, Part II. South Australia Government Printing Division, Adelaide

Wright JT, Benkendorff K, Davis AR (1997) Habitat associated differences in temperate sponge assemblages: the importance of chemical defence. J Exp Mar Biol Ecol 213:199-213

Submitted: March 29, 2000; Accepted: August 15, 2000

Proofs received from author(s): November 9, 2000 